\title{
Effect of Oxide Fluxes on the Viscosity of Molten Aluminothermic Ferro-chrome Slags
}

\author{
R. C. BEHERA and U. K. MOHANTY \\ Department of Metallurgical Engineering, Regional Engineering College, Rourkela, 769008 India. \\ E-mail: rbehera@rec.ori.nic.in
}

(Received on November 24, 2000; accepted in final form on May 9, 2001)

\begin{abstract}
The viscous slag generated during aluminothermic reduction of metallic oxides for production of metals or alloys slows down the reduction process and obstructs clear separation of slag and metal. The fluxing constituents are added to bring down the viscosity.

Hence the effect of variation of $\mathrm{CaO}$ and $\mathrm{MgO}$ contents on the viscosity of synthetically prepared ferrochrome slags having an approximate composition of industrial ferro-chrome slags resulting from aluminothermic reduction of chromium oxide has been studied at various temperatures. Increase of $\mathrm{CaO}$ and $\mathrm{MgO}$ contents is found to decrease the viscosity of the slags. The relative decrease in viscosity becomes very less beyond $40 \mathrm{~mol} \%$ of $\mathrm{CaO}$. It is further observed that both $\mathrm{CaO}$ and $\mathrm{MgO}$ additions do not decrease the viscosity appreciably at higher temperatures as they do at lower temperatures.

The activation energy of viscous flow calculated from the viscosity data, is seen to obey the Arrhenius equation $\left\{\mu=A_{0} \exp \left(E_{\mu} / R T\right)\right.$. The activation energy, $E_{\mu}$ decreases with increased flux addition. It is also observed that the activation energy of viscous flow is independent of temperature but is a function of the composition of the slag. Within the range of compositions studied, the net-work breaking ability of $\mathrm{Mg}^{++}$ ion is not as high as that of $\mathrm{Ca}^{++}$ion. The possible ionic structure of the liquid slags and ionic interactions have been discussed in light of the calculated values of activation energy of viscous flow. $\mathrm{Al}_{2} \mathrm{O}_{3}$ does not behave as an amphoteric oxide as it does in silicate melts.
\end{abstract}

KEY WORDS: aluminothermic; viscosity; activation-energy; ionic structure; ionic interactions; discrete aluminate anions; polymerisation; depolymerisation; co-ordination number; Arrhenius equation; non-bridging oxygen.

\section{Introduction}

The slags generated in the aluminothermic route for production of low carbon ferro-alloys contain high percentages of $\mathrm{Al}_{2} \mathrm{O}_{3}$ along with some un-reduced oxides and some gangue oxides and are expected to exhibit high viscosity values which may interfere with the process of extraction adversely. However, an optimum value of the viscosity of the slags can be obtained through compositional adjustments by addition of fluxing constituents judiciously and by controlling the temperature at suitable levels.

The behavior of alumina in silicate melts has been studied by various authors. ${ }^{1-10)}$ It has been suggested that $\mathrm{Al}^{3+}$ may adopt four-fold or six-fold co-ordination depending on the nature and quantity of other oxides present. The most important factor among others is the $\mathrm{Al}_{2} \mathrm{O}_{3} / \mathrm{CaO}$ ratio. They suggest that at lower values of the ratio only a part of $\mathrm{Al}^{3+}$ ions will be able to assume the tetrahedral co-ordination and the rest of them occupy $\mathrm{AlO}_{6}$ sites thereby disintegrating the alumino-silicate anions. However, when the $\mathrm{Al}_{2} \mathrm{O}_{3}$ / $\mathrm{CaO}$ molar ratio is greater than or equal to unity, $\mathrm{Al}_{2} \mathrm{O}_{3}$ and $\mathrm{SiO}_{2}$ behave similarly. Again Poe et al. ${ }^{9)}$ suggested that the average aluminium coordination increases as a function of increasing alumina content in $\mathrm{CaO}-\mathrm{Al}_{2} \mathrm{O}_{3}$ liquids and hence in these melts both five and six co-ordinated alumini- um species are predominant. Suchilinkov and Pliner ${ }^{11)}$ and Pliner et $a l{ }^{12)}$ have reported viscosity values of a few aluminothermic slags resulting from production of ferrotitanium, ferrochromium, ferroniobium and ferrosilico zirconium at various temperatures and with addition of alkaline earth oxides such as $\mathrm{CaO}, \mathrm{BaO}$ and $\mathrm{SrO}$, but no structural model was suggested.

It is well known that the type, size and structure of various ions present in the slag melt and the interaction among the various ions affect the viscosity of the melts. On the other hand the structure and size of these ions depend on the type and amount of various constituents present in the slag melt.

It is in this context that an attempt has been made in the present investigation to systematically investigate the effects of addition of two alkaline earth oxides namely $\mathrm{CaO}$ and $\mathrm{MgO}$ on the viscosity of the slags at various temperatures. From the viscosity and activation energy data available, the possible structure of the melt has been suggested.

\section{Experimental}

\subsection{Sample Preparation}

Thirteen numbers of slag samples are prepared in the laboratory having compositions most nearly approaching 
Table 1. Compositional details of slag. (Variation of $\mathrm{Al}_{2} \mathrm{O}_{3} / \mathrm{CaO}$ mass ratio)

\begin{tabular}{|c|c|c|c|c|c|c|c|c|c|}
\hline \multicolumn{10}{|c|}{ PERCENTAGE COMPOSITION, mass\%, (mole\%) } \\
\hline $\begin{array}{l}\text { Sl. } \\
\text { No. }\end{array}$ & $\begin{array}{l}\text { Slag } \\
\text { No. }\end{array}$ & $\mathbf{A l}_{2} \mathbf{O}_{3}$ & $\mathrm{CaO}$ & MgO & $\mathrm{Na}_{2} \mathrm{O}$ & $\mathrm{Cr}_{2} \mathrm{O}_{3}$ & $\mathrm{SiO}_{2}$ & $\mathbf{F e O}$ & $\begin{array}{c}\mathrm{Al}_{2} \mathbf{O}_{3} / \mathrm{CaO} \\
\text { (mass ratio) }\end{array}$ \\
\hline 1 & 1 & $\begin{array}{c}57.98 \\
(44.62)\end{array}$ & $\begin{array}{c}22.30 \\
(31.26)\end{array}$ & $\begin{array}{c}4.30 \\
(8.41)\end{array}$ & $\begin{array}{c}5.30 \\
(6.68)\end{array}$ & $\begin{array}{c}4.50 \\
(2.28)\end{array}$ & $\begin{array}{c}2.80 \\
(3.69)\end{array}$ & $\begin{array}{c}2.82 \\
(3.06)\end{array}$ & 2.60 \\
\hline 2 & 2 & $\begin{array}{c}58.25 \\
(44.71) \\
\end{array}$ & $\begin{array}{c}24.27 \\
(33.91) \\
\end{array}$ & $\begin{array}{c}4.20 \\
(8.22) \\
\end{array}$ & $\begin{array}{c}5.05 \\
(6.34) \\
\end{array}$ & $\begin{array}{c}4.40 \\
(2.27)\end{array}$ & $\begin{array}{c}1.90 \\
(2.51) \\
\end{array}$ & $\begin{array}{c}1.90 \\
(2.04) \\
\end{array}$ & 2.40 \\
\hline 3 & 3 & $\begin{array}{c}56.3 \\
(42.59)\end{array}$ & $\begin{array}{c}26.7 \\
(36.80)\end{array}$ & $\begin{array}{c}4.10 \\
(7 . .95)\end{array}$ & $\begin{array}{c}5.00 \\
(6.25)\end{array}$ & $\begin{array}{c}4.30 \\
(2.16)\end{array}$ & $\begin{array}{c}1.80 \\
(2.31)\end{array}$ & $\begin{array}{c}1.80 \\
(1.93)\end{array}$ & 2.10 \\
\hline 4 & 4 & $\begin{array}{c}56.25 \\
(42.88)\end{array}$ & $\begin{array}{c}28.0 \\
(38.91)\end{array}$ & $\begin{array}{c}3.29 \\
(6.38) \\
\end{array}$ & $\begin{array}{r}4.56 \\
(5.76) \\
\end{array}$ & $\begin{array}{c}4.29 \\
(2.18)\end{array}$ & $\begin{array}{c}1.64 \\
(2.10)\end{array}$ & $\begin{array}{c}1.64 \\
(1.79)\end{array}$ & 2.00 \\
\hline 5 & 5 & $\begin{array}{c}55.37 \\
(42.51) \\
\end{array}$ & $\begin{array}{c}30.60 \\
(41.74)\end{array}$ & $\begin{array}{c}3.15 \\
(6.04) \\
\end{array}$ & $\begin{array}{c}4.43 \\
(5.43) \\
\end{array}$ & $\begin{array}{c}3.21 \\
(1.61)\end{array}$ & $\begin{array}{c}1.57 \\
(1.98)\end{array}$ & $\begin{array}{c}1.57 \\
(1.68)\end{array}$ & 1.80 \\
\hline 6 & 6 & $\begin{array}{c}56.48 \\
(42.45) \\
\end{array}$ & $\begin{array}{c}31.48 \\
(43.07) \\
\end{array}$ & $\begin{array}{c}2.78 \\
(5.29) \\
\end{array}$ & $\begin{array}{c}3.70 \\
(4.60) \\
\end{array}$ & $\begin{array}{c}2.78 \\
(1.38)\end{array}$ & $\begin{array}{c}1.39 \\
(1.76) \\
\end{array}$ & $\begin{array}{c}1.39 \\
(1.46)\end{array}$ & 1.79 \\
\hline 7 & 7 & $\begin{array}{c}53.00 \\
(39.01) \\
\end{array}$ & $\begin{array}{c}34.00 \\
(45.54)\end{array}$ & $\begin{array}{c}3.00 \\
(5.63) \\
\end{array}$ & $\begin{array}{c}4.00 \\
(4.88) \\
\end{array}$ & $\begin{array}{c}3.00 \\
(1.50)\end{array}$ & $\begin{array}{c}1.50 \\
(1.88) \\
\end{array}$ & $\begin{array}{c}1.50 \\
(1.58) \\
\end{array}$ & 1.56 \\
\hline 8 & 8 & $\begin{array}{c}51.10 \\
(37.17)\end{array}$ & $\begin{array}{c}36.40 \\
(48.22)\end{array}$ & $\begin{array}{c}2.88 \\
(5.34)\end{array}$ & $\begin{array}{c}3.86 \\
(4.60) \\
\end{array}$ & $\begin{array}{c}2.88 \\
(1.41)\end{array}$ & $\begin{array}{c}1.44 \\
(1.78)\end{array}$ & $\begin{array}{c}1.44 \\
(1.48)\end{array}$ & 1.40 \\
\hline
\end{tabular}

Table 2. Compositional details of slags. (Variation of $\mathrm{MgO}$ at $\mathrm{Al}_{2} \mathrm{O}_{3} / \mathrm{CaO}$ (mass ratio) $=2.5$ )

\begin{tabular}{|c|c|c|c|c|c|c|c|c|c|}
\hline \multicolumn{10}{|c|}{ PERCENTAGE COMPOSITION, mass\% (mole\%) } \\
\hline \begin{tabular}{|c|c|c|c|c|c|c|c|} 
Sl. \\
No.
\end{tabular} & $\begin{array}{l}\text { Slag } \\
\text { No. }\end{array}$ & $\mathbf{A l}_{2} \mathbf{O}_{3}$ & $\mathbf{C a O}$ & $\mathrm{MgO}$ & $\mathrm{Na}_{2} \mathbf{O}$ & $\mathrm{Cr}_{2} \mathbf{O}_{3}$ & $\mathrm{SiO}_{2}$ & $\mathbf{F e O}$ & $\begin{array}{c}\mathbf{A l}_{2} \mathbf{O}_{3} / \mathbf{C a O} \\
(\mathbf{m a s s} \text { ratio) }\end{array}$ \\
\hline 1 & 9 & 60.42 & 24.16 & 4.00 & 4.67 & 3.55 & 1.60 & 1.60 & 2.50 \\
& & $(46.59)$ & $(33.93)$ & $(7.87)$ & $(5.92)$ & $(1.84)$ & $(2.10)$ & $(1.75)$ & \\
\hline 2 & 10 & 58.63 & 23.44 & 6.00 & 4.75 & 3.82 & 1.68 & 1.68 & 2.50 \\
& & $(44.34)$ & $(32.29)$ & $(11.57)$ & $(5.91)$ & $(1.94)$ & $(2.16)$ & $(1.79)$ & \\
\hline 3 & 11 & 58.13 & 23.25 & 8.00 & 4.34 & 3.40 & 1.44 & 1.44 & 2.50 \\
& & $(37.07)$ & $(27.00)$ & $(13.01)$ & $(4.55)$ & $(1.46)$ & $(1.56)$ & $(1.30)$ & \\
\hline 4 & 12 & 56.66 & 22.66 & 10.0 & 4.45 & 3.25 & 1.50 & 1.50 & 2.50 \\
& & $(41.18)$ & $(29.99)$ & $(18.53)$ & $(5.32)$ & $(1.59)$ & $(1.85)$ & $(1.54)$ & \\
\hline 5 & 13 & 55.0 & 22.0 & 12.0 & 4.50 & 3.50 & 1.50 & 1.50 & 2.50 \\
& & $(39.26)$ & $(28.60)$ & $(21.84)$ & $(5.29)$ & $(1.67)$ & $(1.82)$ & $(1.51)$ & \\
\hline
\end{tabular}

Table 3. Chemical analysis of a few random samples.

\begin{tabular}{|c|c|c|c|c|c|c|c|c|c|}
\hline \multicolumn{10}{|c|}{ PERCENTAGE COMPOSITION (mass \%) } \\
\hline $\begin{array}{l}\text { Sl. } \\
\text { No. }\end{array}$ & $\begin{array}{l}\text { Slag } \\
\text { No. }\end{array}$ & $\mathbf{A l}_{2} \mathbf{O}_{3}$ & $\mathbf{C a O}$ & $\mathbf{M g O}$ & $\mathbf{N a}_{2} \mathbf{O}$ & $\mathbf{C r}_{2} \mathbf{O}_{3}$ & $\mathbf{S i O}_{2}$ & $\mathbf{F e O}$ & $\begin{array}{c}\mathbf{A l}_{2} \mathbf{O}_{3} / \mathbf{C a O} \\
\text { (mass ratio) }\end{array}$ \\
\hline 1 & 8 & 50.95 & 36.37 & 2.86 & 3.8 & 3.1 & 1.5 & 1.4 & 1.4 \\
\hline 2 & 4 & 56.22 & 28.05 & 3.28 & 4.5 & 4.3 & 1.7 & 1.68 & 2.0 \\
\hline 3 & 1 & 57.58 & 22.20 & 4.80 & 5.32 & 4.5 & 2.9 & 2.7 & 2.6 \\
\hline 4 & 10 & 58.70 & 23.48 & 5.95 & 4.72 & 3.8 & 1.7 & 1.6 & 2.5 \\
\hline 5 & 13 & 55.05 & 22.0 & 11.85 & 4.60 & 3.43 & 1.6 & 1.3 & 2.5 \\
\hline
\end{tabular}

the compositions encountered in practice, resulting from aluminothermic reduction of chromite ore for production of ferro-chrome. The slags are divided into two groups.

The first group of slags, eight in number have $\mathrm{Al}_{2} \mathrm{O}_{3} / \mathrm{CaO}$ mass ratio varying from 1.4 to 2.6. The second group consists of five different compositions where $\mathrm{MgO}$ content is varied from 4.0 to 12.0 mass $\%$ at a fixed mass ratio of $\mathrm{Al}_{2} \mathrm{O}_{3} / \mathrm{CaO}$ at 2.5 .

The composition of the above 13 samples have been so chosen to vary the above two parameters that the other constituents namely $\mathrm{SiO}_{2}, \mathrm{FeO}, \mathrm{Na}_{2} \mathrm{O}$ and $\mathrm{Cr}_{2} \mathrm{O}_{3}$ are adjusted with minor variations, to make the total $100 \%$. Such minor variations are well within the range of composition of aluminothermic ferro-chrome slags.

The powdered oxides used are of laboratory grade with 98.5-99.5\% purity. After calcination (wherever required) they are weighed in predetermined proportions, mixed in planetary ball mill for $24 \mathrm{hr}$, melted in platinum crucibles, cooled, crushed and remelted with a holding time of $4 \mathrm{hr}$. Homogenisation of the synthetic slags so prepared is checked by XRD. The detailed compositions of the slags are presented in Table 1 and Table 2 respectively. Some random samples are taken for chemical analysis after homogenisation, i.e. melting and remelting; their composition is presented in Table 3. The results of this analysis show that all the constituents practically do not undergo any change after homogenisation.

\subsection{Viscosity Measurements}

The melting and viscosity measurements are carried out in a self-fabricated graphite resistance furnace which is powered through a three phase to one phase step down transformer and dimmerstat. The temperature of the heating zone of the furnace could be controlled within $\pm 3 \mathrm{~K}$ in the range of $1773-2023 \mathrm{~K}$. A Pt. 6\% Rh-Pt. 30\% Rh thermocouple is used for temperature measurement. Anhydrous argon is used for maintaining an inert atmosphere in the furnace to protect the graphite resistors as well as the molybdenum crucible holding the molten slag and the molybdenum spindle and bob assembly.

An inner cylinder rotating type viscometer, namely Brookfield-synchrolectric viscometer, RVT model, fitted with a molybdenum spindle and bob assembly, is used for viscosity measurement.

The complete viscometer assembly along with the graphite furnace is shown in Fig. 1.

The viscometer is calibrated in the working set-up using standard silicone fluids. Calibration curves are drawn with viscosity Vs dial readings at three different speeds of the motor, viz-1.0 rpm, $2.5 \mathrm{rpm}$ and $5.0 \mathrm{rpm}$. The measurement is taken at these three speeds.

The measurement is carried out at various temperatures in increasing order at an interval of $20-25 \mathrm{~K}$ up to maximum temp. level of $2023 \mathrm{~K}$ because the thermocouple used failed at higher temperatures. The measurement is repeated 


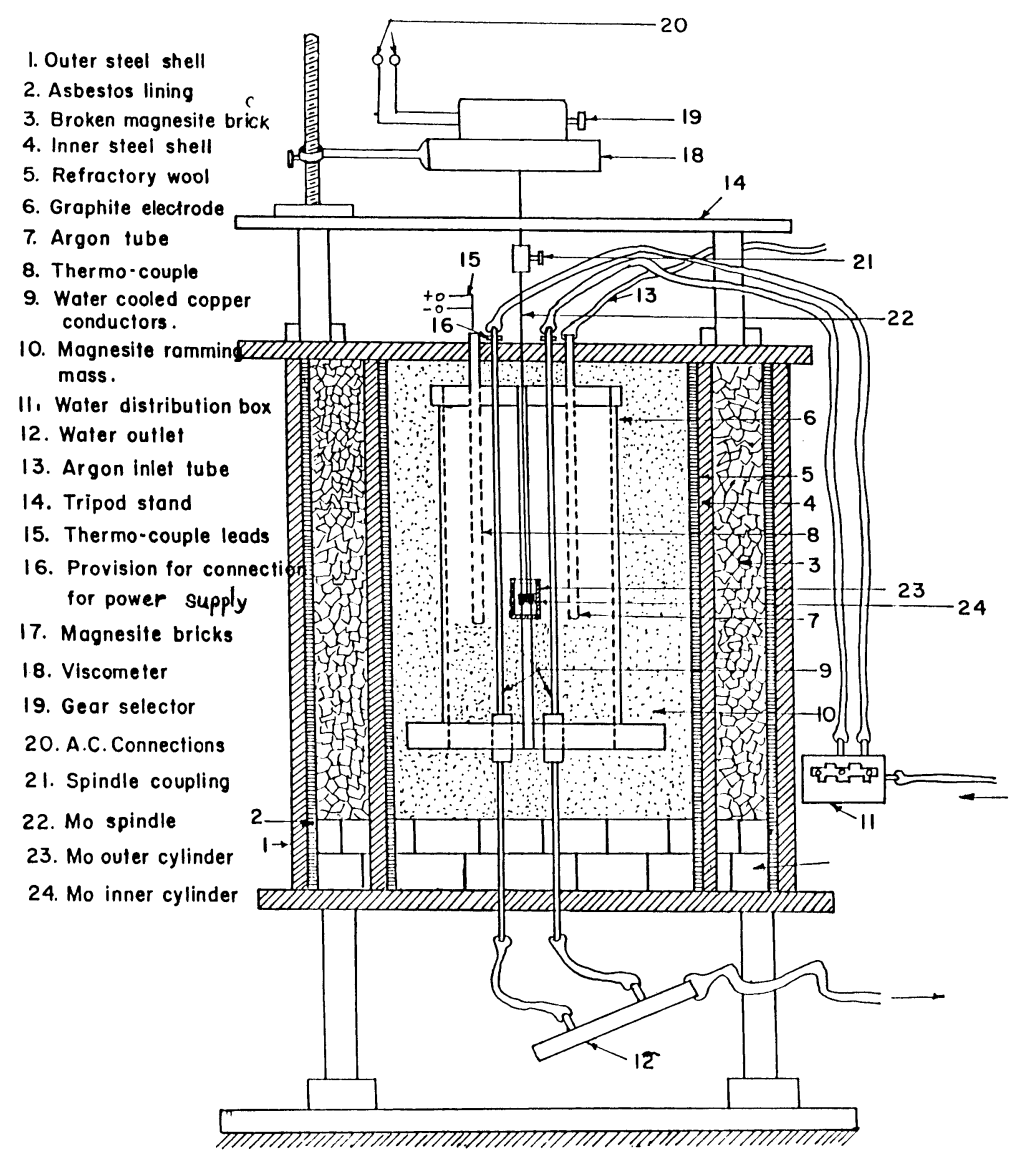

Fig. 1. Details of experimental set-up for viscosity measurements.

at the same temperature during cooling from the highest temperature till the measurement becomes impossible due to very high viscosity of the sample. The average of the two readings is reported if the difference between the two temperatures (rising and falling) is within 0 to $5 \mathrm{~K}$. In case the difference is more than $5 \mathrm{~K}$ the sample is rejected, fresh sample is taken and the whole process of measurement is repeated.

\section{Results and Discussion}

The measured viscosity data have been plotted against temperature for these thirteen slags split into two groups. A detailed analysis has been made with the help of the viscosity isotherms at various temperatures and the variation of the activation energy of viscous flow at different $\mathrm{CaO}$ and $\mathrm{MgO}$ contents.

\subsection{Variation of $\mathrm{CaO}$}

Figure 2 shows the variation of viscosity with temperature from which it appears that most of the slags except slag No. 8 are short slags, i.e. slags whose viscosity increases abruptly with a small decrease in temperature. The same observation was also made while measuring fusion behaviour of these slags. In such slags the temperature should be closely monitored and should not be allowed to fall below a certain value in which case the slag becomes highly viscous thus hindering the reduction process as well as the separation of the metal and the alloy from the slag.

Figure 3 shows the viscosity isotherms of these slags at

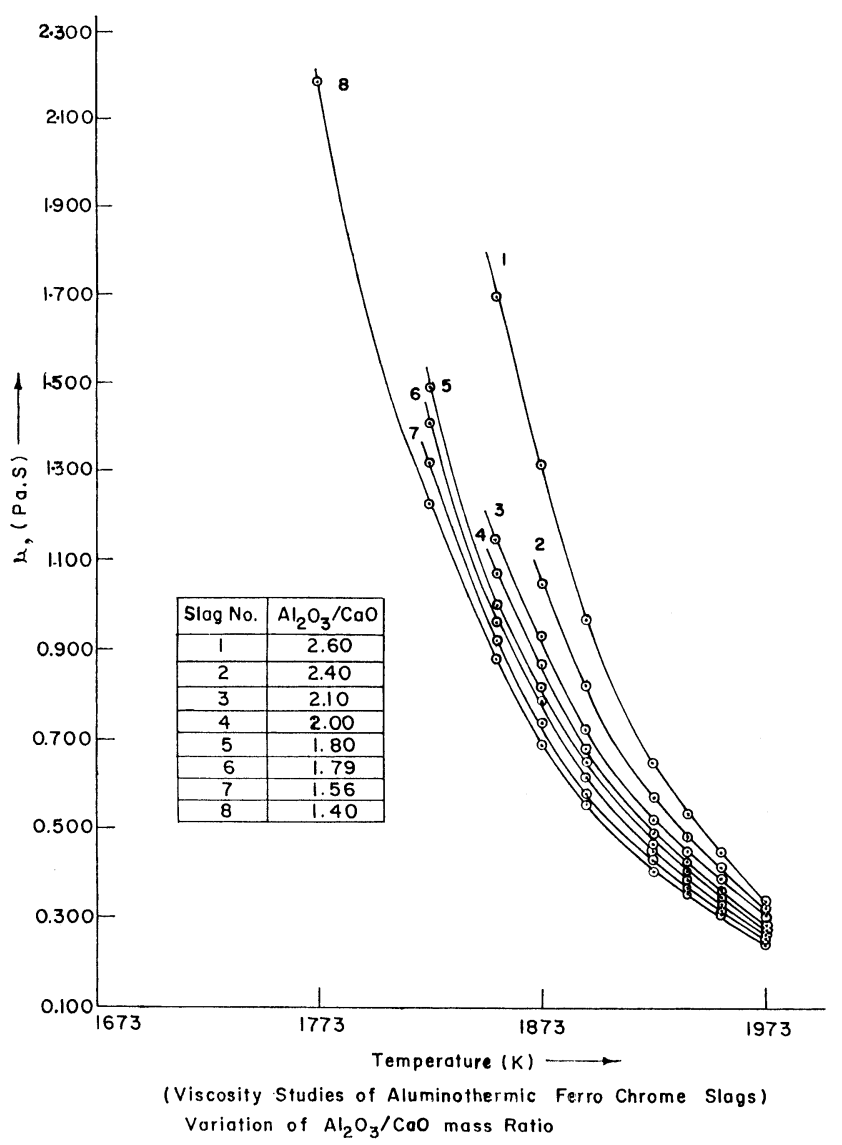

Fig. 2. Relationship between viscosity and temperature (Variation of $\mathrm{Al}_{2} \mathrm{O}_{3} / \mathrm{CaO}$ mass Ratio) 


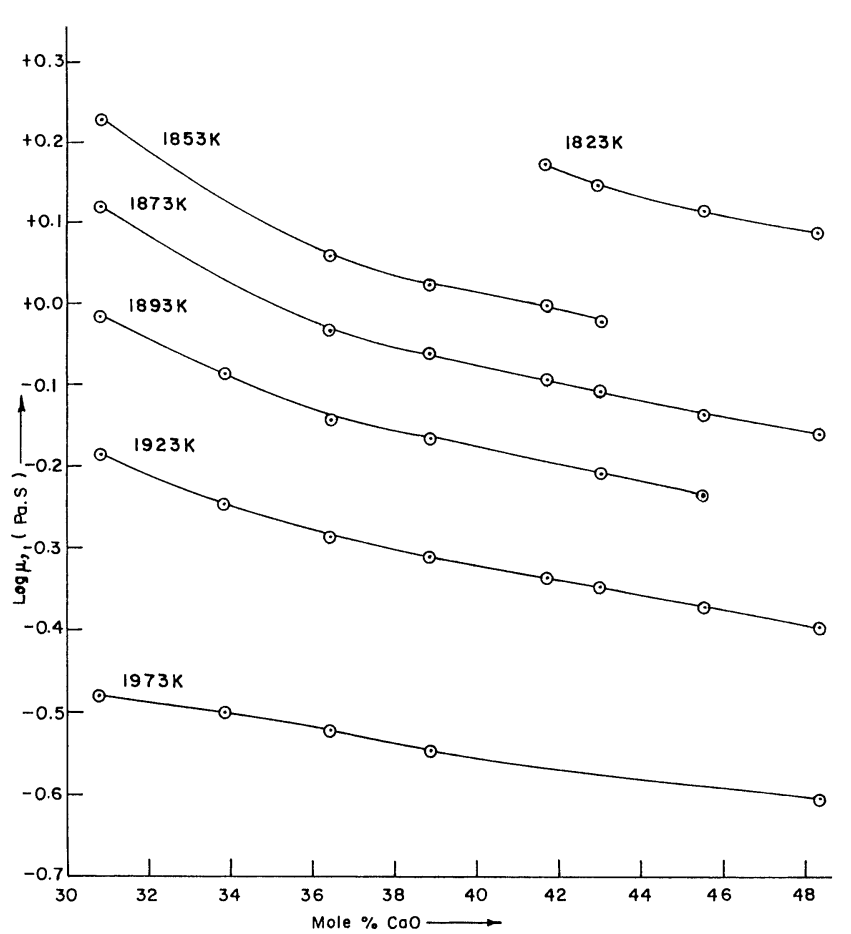

(Viscosify Studies of Aluminothermic Ferrochrome Slags; Variotion of $\mathrm{Al}_{2} \mathrm{O}_{3} / \mathrm{CoO}$ mass Ratio)

Fig. 3. Relationship between $\log \mu$ and $\mathrm{mol} \% \mathrm{CaO}$ at specific temperatures.

various temperatures. It is clear from the figures that although increase of $\mathrm{CaO}$ content (or decrease of $\mathrm{Al}_{2} \mathrm{O}_{3} / \mathrm{CaO}$ ratio) continuously decreases the viscosity, the relative decrease becomes very less beyond $40 \mathrm{~mol} \%$ of $\mathrm{CaO}$ (equivalent to between 28.0 and 30.6 mass $\% \mathrm{CaO}$ ). Within the slag composition studied, a minimum viscosity value of $0.248 \mathrm{~Pa} \cdot \mathrm{s}$ is obtained at $48.37 \mathrm{~mol} \%$ (36.54 mass\%) of $\mathrm{CaO}$ at $1973 \mathrm{~K}$.

Another important observation that may be made in the above figure is that at higher temperatures the curves flatten out indicating that increase of $\mathrm{CaO}$ content does not appreciably affect the viscosity at higher temperature as it does at lower temperatures. This demonstrates that at high temperature the contribution of weakening the ionic bonds between cations and discrete aluminate anions to the decrease of viscosity is more predominant than that made by breakdown of bigger anionic units to smaller flow units. Hence, when the processes will be carried out at low temperatures higher amount of $\mathrm{CaO}$ flux has to be added.

Figure 4 which shows the logarithmic variation of viscosity against inverse temperature (absolute), confirms that viscosity obeys the general relationships $\mu=A_{0} \exp \left(E_{\mu} / R T\right)$. The decrease of viscosity with temperature and the straight line relationship between $\log \mu$ and $1 / T$ [i.e., constant activation energy] demonstrates that the decrease of viscosity with increase in temperature is due only to weakening of the ionic bonds between cations $\left(\mathrm{Ca}^{++}\right)$and the discrete aluminate anions. As there is no change of activation energy, the degree of polymerisation is practically constant for a given composition at various temperatures. This means discrete anions do not breakdown to small units with increase in temperature. The graphs of Fig. 4 are utilized to estimate the activation energy of viscous flow, $E_{\mu}$.

Figure 5 illustrates the variation of $E_{\mu}$ with $\mathrm{mol} \% \mathrm{CaO}$

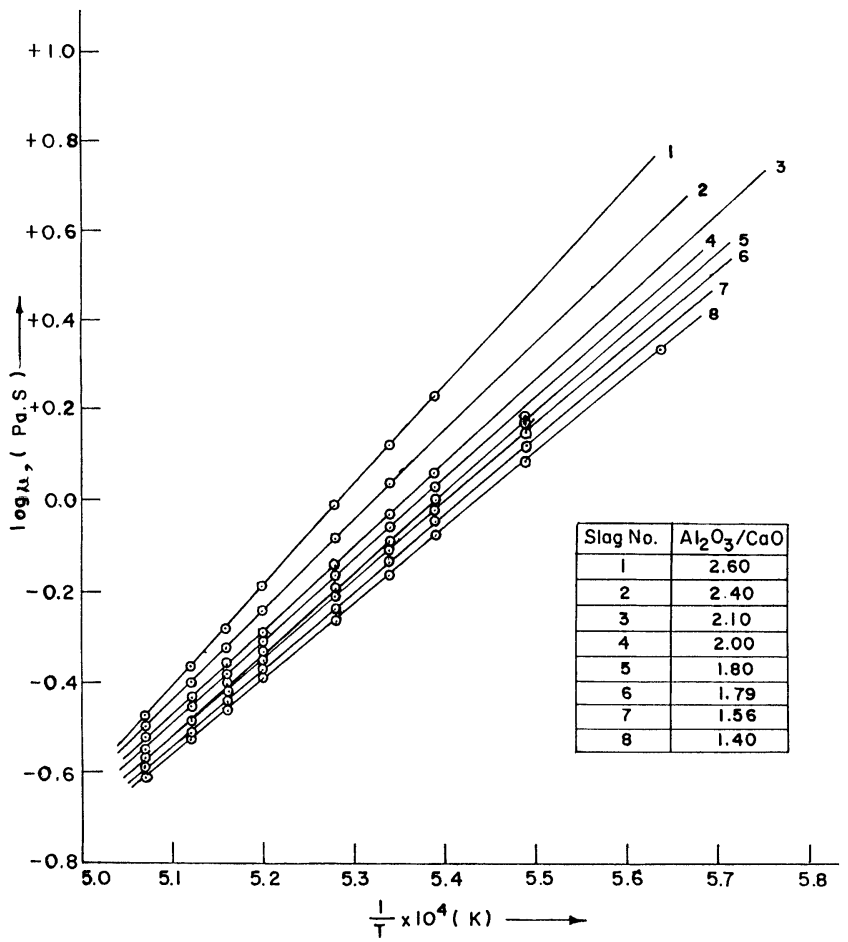

(Viscosity Studies of Alumino thermic Ferro-Chrome Slags; Variation of $\mathrm{Al}_{2} \mathrm{O}_{3} / \mathrm{CaO}$ mass Ratiol

Fig. 4. Relationship between $1 / T \times 10^{4}$ and $\log \mu$.

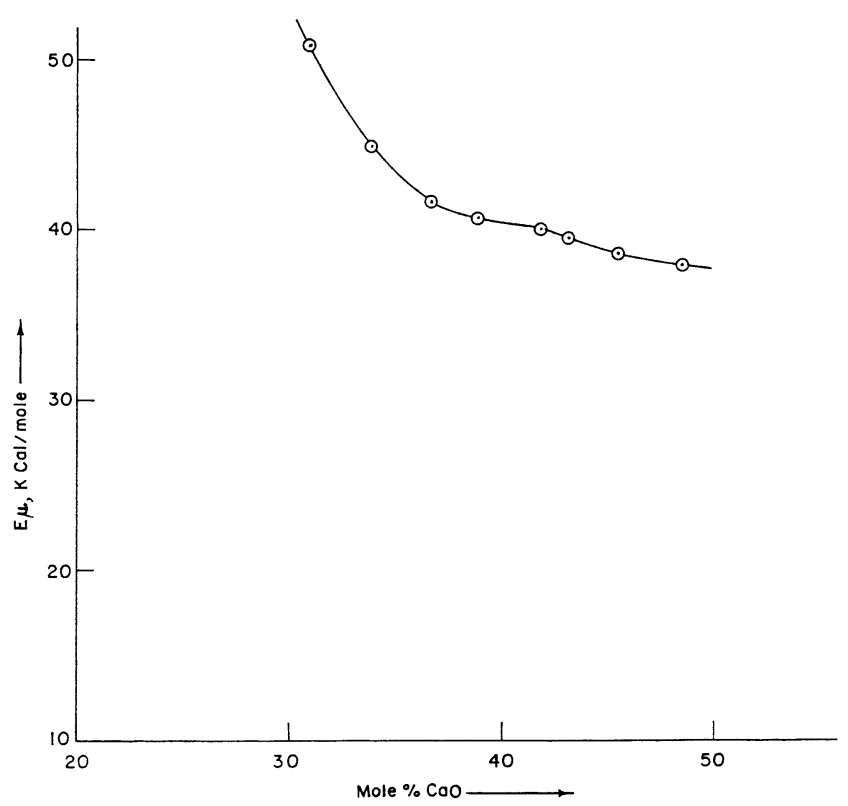

(Viscosity Studies of Aluminothermic Ferro-Chrome Slags; Variotion of $\mathrm{Al}_{2} \mathrm{O}_{3} / \mathrm{CoO}$ mass Ratio)

Fig. 5. Relationship between activation energy of viscous flow $\left(E_{\mu}\right)$ and $\mathrm{mol} \% \mathrm{CaO}$.

in the slags. It is observed from this figure that the activation energy for viscous flow continuously decreases with increase in $\mathrm{CaO}$ content in the slag from a value of $51 \mathrm{kcal} / \mathrm{mol}$ to about $38 \mathrm{kcal} / \mathrm{mol}$, however, the rate of decrease is lower at higher $\mathrm{CaO}$ contents. This small decrease of activation energy of viscous flow, within the composition studied, suggests that the change of size of the aluminate groups is small and hence the number of associated negative charges decrease at a slower rate. Thus the number of 
ionic bonds which have to be broken or distorted to enable the flow units to move become less and hence there is a slower decrease of $E_{\mu}$. The slower decrease of activation energy of viscous flow may be also due to small increase of repulsions between few single bonded oxygen of different aluminate flow units and also a small decrease of metaloxygen attraction.

From the above observation it is clear that progressive addition of $\mathrm{CaO}$ to the slag changes the alumina structure to form smaller flow units and hence decrease the viscosity as well as the activation energy of viscous flow. In a recent investigation into the structure of calcium aluminate liquids by high temperatures 27 Al NMR and Raman Spectroscopy, Poe and Macmillan ${ }^{9}$ ) have established that aluminium has variable co-ordination number ranging from 4 to 6 and the extent of these various aluminium coordinated species, $\mathrm{AlO}_{n}$ with $n=4,5$ and 6 depends on the composition of the melt. In the present investigation alumina mol\% varies from a value of 37 to 44 and within this range both $\mathrm{AlO}_{4}^{5-}$ and $\mathrm{AlO}_{5}^{7-}$ species are assumed to be present and their distribution contributes to change of viscosity. The progressive decrease of viscosity with increase of $\mathrm{CaO}$ content demonstrates that there is an increase in the proportion of $\mathrm{AlO}_{5}^{7-}$ and decrease in the proportion of $\mathrm{AlO}_{4}^{5-}$ as the latter species forms more polymerized units.

It may further be noted that unlike silicate melts $\mathrm{Al}_{2} \mathrm{O}_{3} /$ $\mathrm{CaO}$ ratio has the same effect on viscosity throughout the composition studied, i.e. at any given temperature the viscosity continuously decreases with decrease in $\mathrm{Al}_{2} \mathrm{O}_{3} / \mathrm{CaO}$ molar ratio from 1.4 to 0.765 . Hence alumina in such slag melts does not behave as an amphoteric oxide.

\subsection{Variation of $\mathrm{MgO}$}

After assessing the positive effect of $\mathrm{CaO}$ on viscosity it was decided to keep the $\mathrm{CaO}$ content around 22-24 mass \% and increase the $\mathrm{MgO}$ content from 4.0 mass $\%$ and above, i.e., partly replacing $\mathrm{CaO}$ by $\mathrm{MgO}$.

It is observed that an increase of $\mathrm{MgO}$ decreases viscosity at all temperatures. For all the 5 slags studied in the range of 4.0 and 12.0 mass $\% \mathrm{MgO}$, the viscosity decreases with temperature, the decrease being sharp for slags with low $\mathrm{MgO}$, as observed in Fig. 6. It is further observed from the above figure that slags consisting of 4-6 mass $\% \mathrm{MgO}$ are short slags and beyond $6-8$ mass $\% \mathrm{MgO}$ in the slags the change of viscosity with temperature becomes gradual. The same conclusion was also drawn from the liquidus temperature tests of these slags.

The viscosity isotherms of these slags presented in Fig. 7 show a similar nature as that of $\mathrm{CaO}$ variaton, i.e., increase of $\mathrm{MgO}$ beyond $13 \mathrm{~mol} \%$ ( 8 mass $\%$ ) in a slag containing about 23 mass $\% \mathrm{CaO}$ lowers viscosity in a decreasing rate. Hence $\mathrm{MgO}$ beyond $13 \mathrm{~mol} \%$ is not very much effective in lowering the viscosity. As in case of $\mathrm{CaO}$, contribution of $\mathrm{MgO}$ in lowering the viscosity is higher at low temperature than at high temperature. Hence, so far as effect on viscosity is concerned the $\mathrm{CaO}$ is replaceable by $\mathrm{MgO}$ on molar basis. Similar observations have been made in silicate melts by many investigators. ${ }^{3,8,13-16)}$

These slags are also seen to obey the Arrhenius equation for viscous flow as is evident from Fig. 8. The activation energy for viscous flow is found to continuously decrease

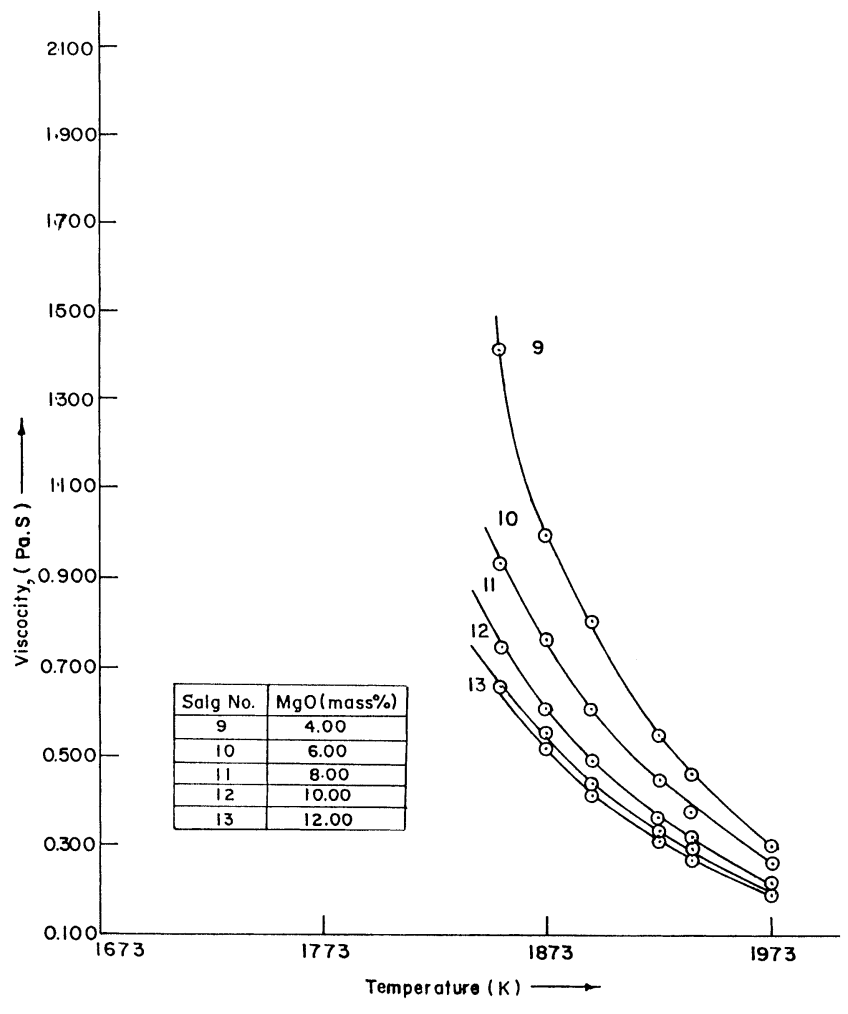

(Viscosity Studies of Alumino-thermic Ferro-chrome Slags, Variation of Mgo)

Fig. 6. Relationship between viscosity and temperature. (Variation of $\mathrm{MgO}$ )

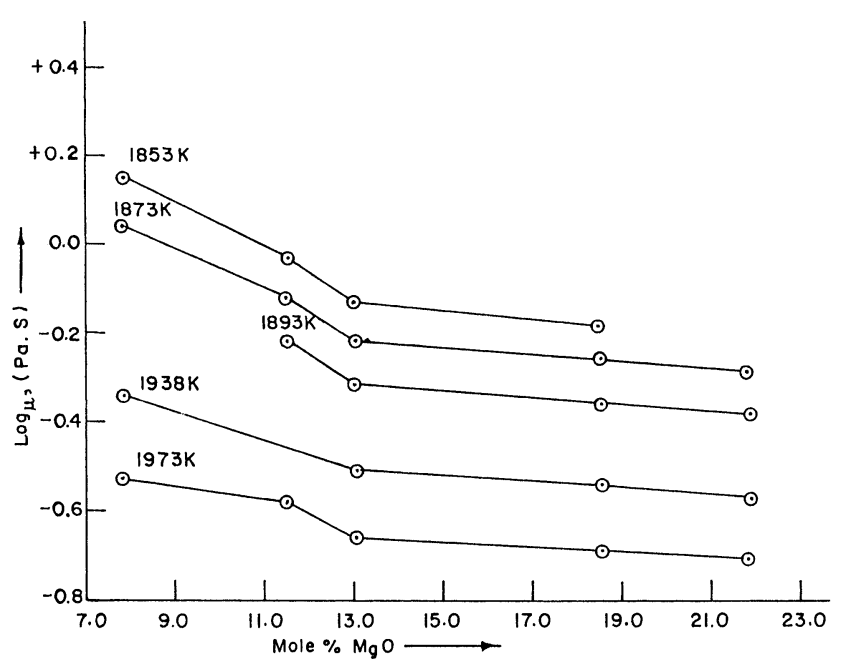

(Viscosity Studies of Alumino Thermic Ferro-chrome Slags;Variation of mole Percent $\mathrm{MgO}$ )

Fig. 7. Relationship between $\mathrm{mol} \% \mathrm{MgO}$ and $\log \mu$ at specific temperatures.

(Fig. 9) from a value of $48.69 \mathrm{kcal} / \mathrm{mol}$ at $4.0 \mathrm{mass} \%(7.87$ $\mathrm{mol} \%) \mathrm{MgO}$ to $32.67 \mathrm{kcal} / \mathrm{mol}$ at $12.0 \mathrm{mass} \%$ (21.84 $\mathrm{mol} \%$ ) $\mathrm{MgO}$, indicating that less amount of energy is required to break the bond for necessary viscous flow as the $\mathrm{MgO}$ content is increased. These values are comparable to the activation energy values obtained for slags with increasing $\mathrm{CaO}$ contents. Likewise, the decrease in activation energy beyond $13 \mathrm{~mol} \% \mathrm{MgO}$ is very less (Fig. 9). This demonstrates that the change of structure of aluminate slags with $\mathrm{CaO}$ or equivalent quantity of $\mathrm{MgO}$ is similar. $\mathrm{Mg}^{++}$ions like $\mathrm{Ca}^{++}$ions have low ion oxygen attraction $(I<0.7)$ and are supposed to be network breakers, because these cations are 


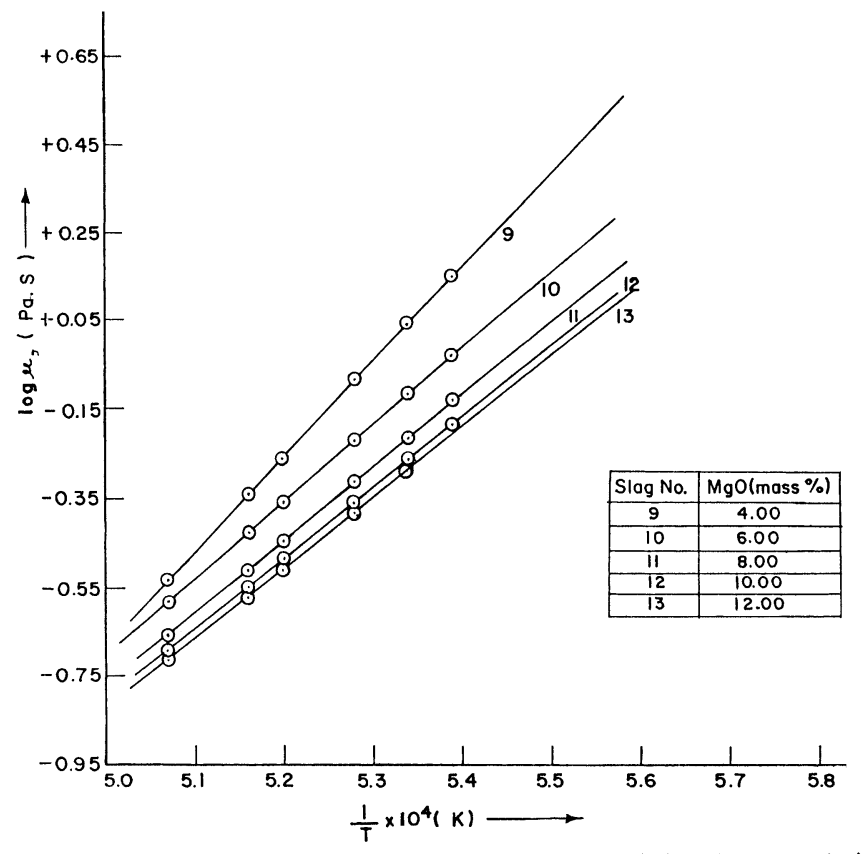

Fig. 8. Relationship between $1 / T \times 10^{4}$ and $\log \mu$.

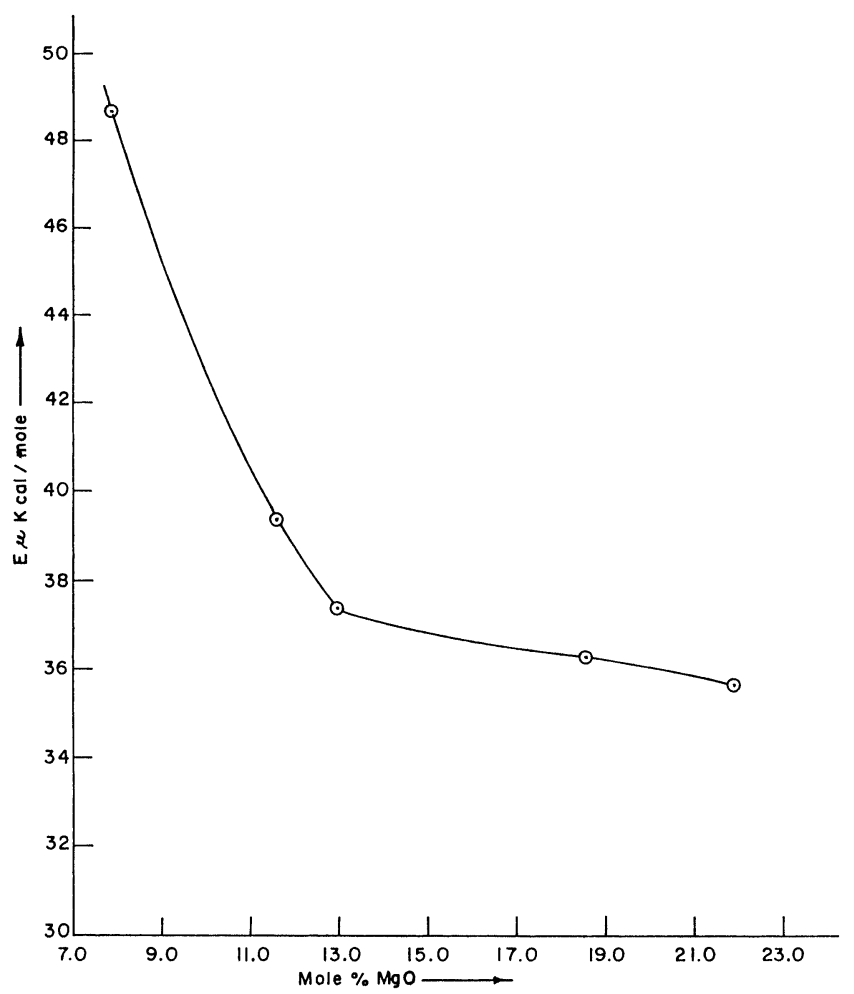

(Viscosity Studies of Aluminothermic Ferrochome Slogs;Variation of mole Percent $\mathrm{MgO}$ )

Fig. 9. Relationship between $\mathrm{mol} \% \mathrm{MgO}$ and activation energy of viscous flow $\left(E_{\mu}\right)$.

unable to build a network. It may be mentioned here that ' $I$ ' known as the ion oxygen interaction parameter of the cations is responsible for holding of the oxygen ions in a particular type of packing. As the cations like $\mathrm{Al}^{3+}, \mathrm{Si}^{4+}$, $\mathrm{Ti}^{4+}$ have higher value of ion oxygen interaction $(I>1.16)$, the oxygen ions are held together tightly and hence they are network former. However, as $Z / r^{2}$ value (where ' $Z$ ' is the valency and ' $r$ ' is the radius of the cation) of $\mathrm{Mg}^{++}$is high-

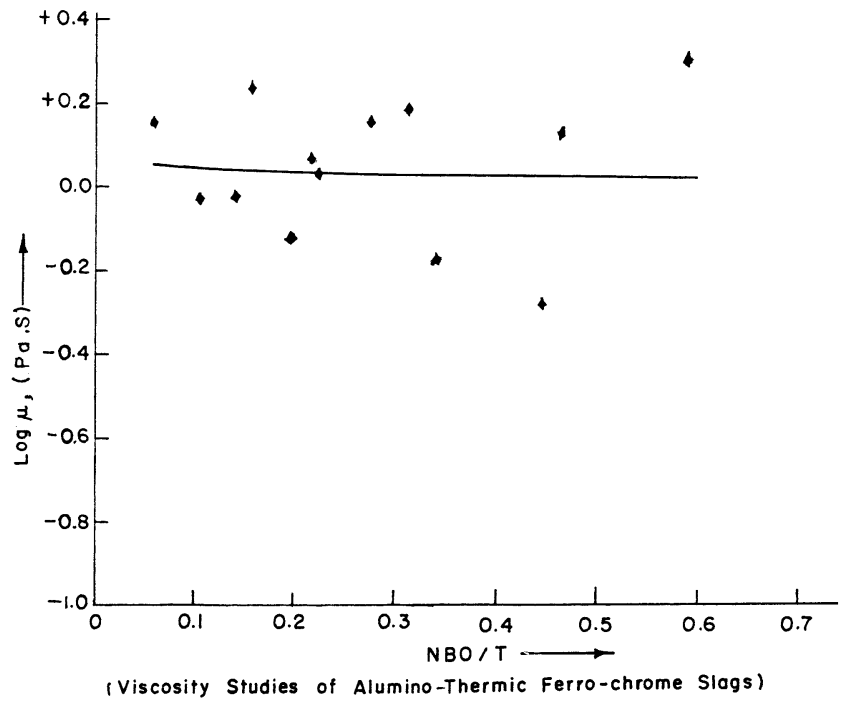

Fig. 10. Relationship between $\mathrm{NBO} / \mathrm{T}$ and $\log \mu$ at temperatures close to liquidus temperature.

er than that of the $\mathrm{Ca}^{++}$, its network breaking ability is not as high as that of calcium ion.

Though the increase of $\mathrm{MgO}$ content up to $12 \mathrm{mass} \%$ shows a decreasing trend of viscosity, $\mathrm{MgO}$ beyond this value is not desirable as higher $\mathrm{MgO}$ content increases the liquidus temperature.

However the effect of $\mathrm{MgO}$ has been studied only at a single ratio of $\mathrm{Al}_{2} \mathrm{O}_{3} / \mathrm{CaO}\left(\mathrm{Al}_{2} \mathrm{O}_{3} / \mathrm{CaO}\right.$ mass ratio is kept at 2.5 for all the five numbers of slags studied). Its effect at various $\mathrm{Al}_{2} \mathrm{O}_{3} / \mathrm{CaO}$ ratios may be studied before drawing a final conclusion on its behaviour in aluminate melts. The degree of depolymerisation in oxide melts, especially the silicates has been indicated by a term $(\mathrm{NBO} / \mathrm{T})$ ratio by Mills. ${ }^{17)}$ This is defined by the number of non-bridging oxygens per tetrahedrally coordinated atoms and calculated from the relationship.

$$
\mathrm{NBO} / \mathrm{T}=Y_{\mathrm{NB}} / X_{\mathrm{T}}
$$

where $Y_{\mathrm{NB}}=2[x(\mathrm{CaO})+x(\mathrm{MgO})+x(\mathrm{FeO})+x(\mathrm{MnO})$

$$
\begin{aligned}
& \left.+x\left(\mathrm{Na}_{2} \mathrm{O}\right)+x\left(\mathrm{~K}_{2} \mathrm{O}\right)\right]-2 x\left(\mathrm{Al}_{2} \mathrm{O}_{3}\right) \\
X_{\mathrm{T}}= & x\left(\mathrm{SiO}_{2}\right)+2 x\left(\mathrm{Al}_{2} \mathrm{O}_{3}\right)
\end{aligned}
$$

' $x$ ' being the mole fraction of the respective oxide.

The logarithmic viscosity of all the thirteen numbers of slags containing various $\mathrm{CaO}$ and $\mathrm{MgO}$ contents at temperatures near the respective liquidus temperature and at $1893 \mathrm{~K}$, are plotted against (NBO/T) and presented in Fig. 10 and Fig. 11 respectively. In Fig. 10 many points are very much apart due to the difference in the liquidus temperatures of the respective slags. In Fig. 11 it is seen that at a particular temperature $(1893 \mathrm{~K})$ the viscosity is very much a function of the degree of depolymerisation. Activation energy $E_{\mu}$ also changes with the degree of polymerisation. The curve of Fig. 12 which is obtained with a close fit of $E_{\mu}$ values against $(\mathrm{NBO} / \mathrm{T})$, supports this fact strongly.

\section{Conclusion}

An increase of $\mathrm{CaO}$ content (or decrease of $\mathrm{Al}_{2} \mathrm{O}_{3} / \mathrm{CaO}$ ratio) as well as $\mathrm{MgO}$ content continuously decreases the 


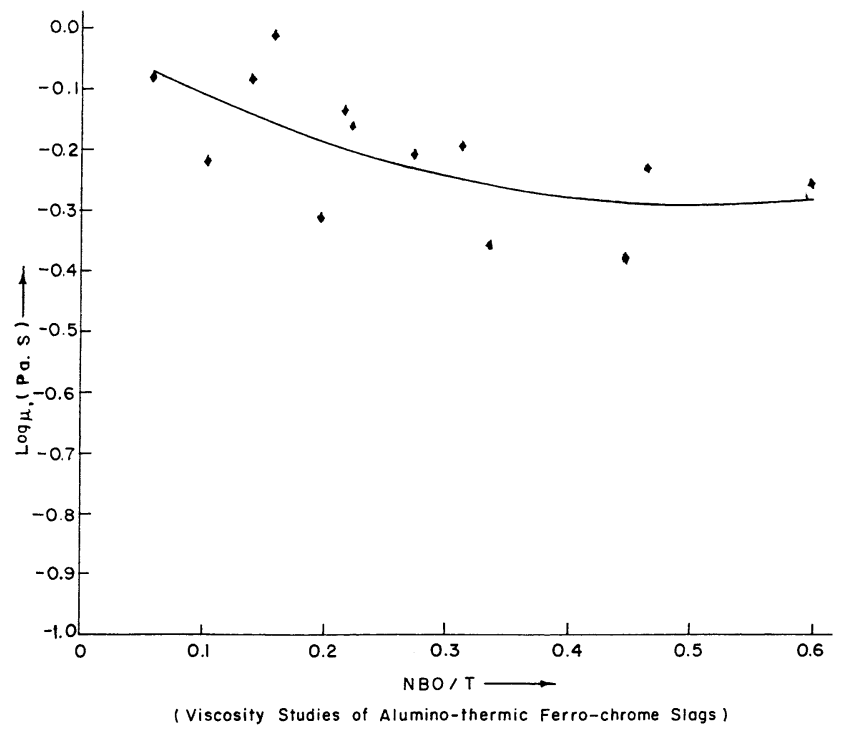

Fig. 11. Relationship between NBO/T and $\log \mu$ at $1893 \mathrm{~K}$.

viscosity. The relative decrease in viscosity becomes very less beyond $40 \mathrm{~mol} \%$ of $\mathrm{CaO}$. However $\mathrm{CaO}$ does not decrease the viscosity appreciably at higher temperature as it does at lower temperature. Activation energy of all the slags is independent of temperature but alters with composition varying from $51 \mathrm{kcal} / \mathrm{mol}$ to $38 \mathrm{kcal} / \mathrm{mol}$ with decrease in $\mathrm{Al}_{2} \mathrm{O}_{3} / \mathrm{CaO}$ ratio and is lowered down from $48.69 \mathrm{kcal} / \mathrm{mole}$ to $32.67 \mathrm{kcal} / \mathrm{mol}$ with $\mathrm{MgO}$ varying from 4.0 to 12.0 mass $\%$ at $\mathrm{Al}_{2} \mathrm{O}_{3} / \mathrm{CaO}$ ratio of 2.5. Like $\mathrm{CaO}$, contribution of $\mathrm{MgO}$ in lowering the viscosity is higher at low temperatures than at high temperatures. The decrease of activation energy of viscous flow beyond $13.0 \mathrm{~mol} \%$ of $\mathrm{MgO}$ is very less demonstrating that the network breaking ability of $\mathrm{Mg}^{++}$ion is not as high as that of $\mathrm{Ca}^{++}$ion.

\section{REFERENCES}

1) W. A. Weyl., J. Soc. Glass Tech., 35 (1951), 421.

2) P. Kozakevitch: Int. Symp. on Phy. Chem. of Process Metallurgy,

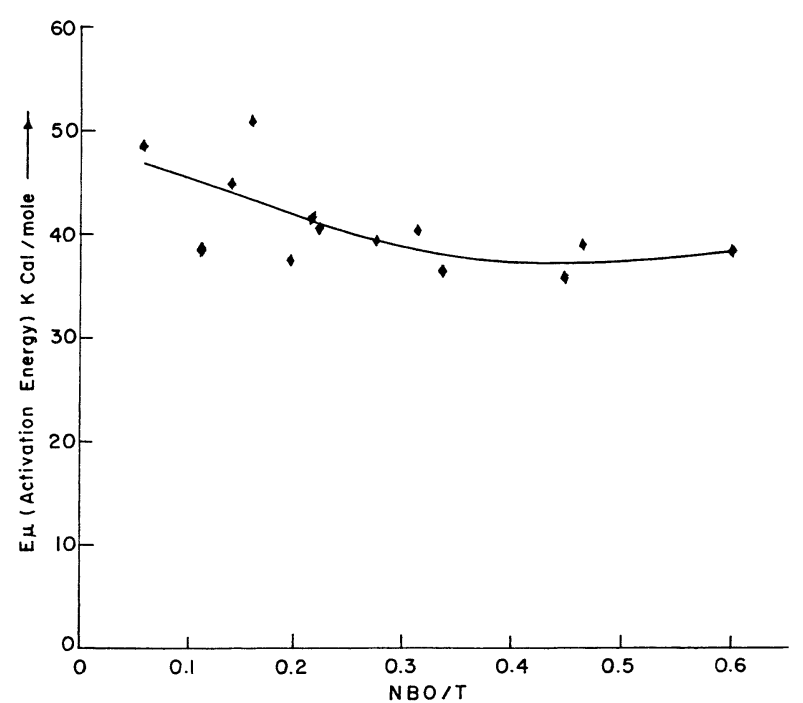

(Viscosity Studies of Alumino-thermic Ferro-chrome Siogs)

Fig. 12. Relationship between $\mathrm{NBO} / \mathrm{T}$ and activation energy of viscous flow.

Vol. 7, AIME, New York, (1959), 97.

3) J. S. Machin and D. L. Hanna: J. Am. Ceram. Soc., 28 (1945), 310.

4) H. Moore and P. W McMillan: J. Soc. Glass Tech., 40 (1956), 193

5) V. Seshadri and V. K. Gupta: Arch. Eisenhüttenwes., 45 (1974), 337.

6) H. Ditz and G. W. Schulz: Glass Tech. Ber., 42 (1969), 89.

7) V. K. Gupta and V. Seshadri: Silver Jublee Symposium, Proc. Melt, Ind. Inst. Met., Calcutta, (1972), 203.

8) E. T. Turkdagan and P. M. Bills: Am. Ceram. Soc. Bull., 39 (1960), 682.

9) Poe, T. Brent, F. Paul and McMillan: J. Am. Ceram. Soc., 77, (1994), No. $7,1832$.

10) G. Urbain: Rev. Int. Hautes Temp. Réfract., 20 (1983), 135.

11) S. I. Suchlinkov and Y. L. Pliner: STAL in English, 11 (1961), 822.

12) Y. L. Pliner, S. V. Shtengelcier, S. C. Mikhaililinkov, F. G. Ignatenko and E. A. Rubinshtein: STAL in English, 4 (1966), 284.

13) J. S. Machine and T. B. Yee: J. Am. Ceram. Soc., 31, (1948), 200.

14) J. S. Machine, T. B. Yee and D. L. Hanna: J. Am. Ceram. Soc., 35 (1952), 322.

15) J. S. Machine and T. B. Yee: J. Am. Ceram. Soc., 37 (1954), 177.

16) Yakusev, V. M. Romashin and V. A. Amfiteatrov: Steel USSR, 7 (1977), 617.

17) K. C. Mills: ISIJ Int., 33 (1993), 148. 